\title{
Simplified process of extraction of polyphenols from agroindustrial grape waste
}

\author{
Larry Oscar CHAÑI-PAUCAR ${ }^{1,2}$, Jose Wesley Lima SILVA³ ${ }^{3}$ Maria Inês Sucupira MACIEL ${ }^{1 \star ~} \mathbb{0}$, \\ Vera Lúcia Arroxelas Galvão de LIMA ${ }^{1}$
}

\begin{abstract}
The extraction, and stability of polyphenols from the grape residue were studied. The extractions were performed following the Box-Behnken design, and the surface response methodology was used to model the extraction of total anthocyanins (TA), flavonols (TF), and phenolics (TP). The extraction was optimized simultaneously by the desirability function. The degradation kinetics of monomeric anthocyanins, and the increase in polymeric color were modeled under refrigeration conditions. The extraction with a temperature of $60^{\circ} \mathrm{C}$, solid:liquid ratio of $1 / 25 \mathrm{~g} / \mathrm{mL}$, and time of $80 \mathrm{~min}$, maximized the recovery of TA $(30.96 \mathrm{mg} / 100 \mathrm{~g})$, TF $(73.34 \mathrm{mg} / 100 \mathrm{~g})$, and TP $(856.78 \mathrm{mg}$ EAG/100 g). The degradation of monomeric anthocyanins, and the increase in polymeric color followed a kinetic first-order reaction, with reaction rates $(\mathrm{k})$ of $4.10 \times 10^{-3}$ days $^{-1}$, and $3.46 \times 10^{-3}$ days $^{-1}$, respectively. The half-life $\left(\mathrm{t}_{1 / 2}\right)$ of anthocyanins was 169 days. The ethanol-citric acid solution allowed polyphenols to be efficiently extracted from the grape residue, and had a positive effect on the stability of anthocyanins.
\end{abstract}

Keywords: Box-Behnken design; phytochemicals; grape residue; solid-liquid extraction.

Pratical Application: Extraction of antioxidant compounds from agroindustrial residues of grapes for food use.

\section{Introduction}

One of the industries historically, and economically important in many countries of the world is the processing of grapes, as they are obtained from various products such as wine, raisins, juices, jellies, among others. The grape fruit is recognized for its nutritional properties and beneficial to health due to its bioactive compounds (Dhekney, 2016).

The wine, and grape juice industries generate abundant waste, which causes additional costs for its elimination (DevesaRey et al., 2011; Mammadova et al., 2020). These residues are approximately $30 \%$ by weight of the fruit used in processing, consisting of seeds, husks, and stalks (Teixeira et al., 2014). Many investigations point out that residues derived from fruit processing present phytochemicals (Morais et al., 2015), with antioxidant properties (O'Shea et al., 2012; Ribeiro et al., 2018), of which phenolic compounds have been reported frequently (Bataglion et al., 2015).

The grape residue is a potential source of phenolic compounds (Goula et al., 2016), of this group, stands out the anthocyanins for their ability to confer color, and functional properties, which can be used in the elaboration of functional foods (Aguilera et al., 2016). Recently, powdered grape residues were used in the ice cream formulation (Vital et al., 2018), and yogurt (Mammadova et al., 2020), improving their functional properties. Grape seed extracts were used to enrich milk for yogurt processing, observing an alteration of the fermentation time, and the yogurt quality attributes (Alwazeer et al., 2020). Although the results are promising, the use of $\mathrm{HCl}$ in the obtaining bioactive extracts represents a potential risk to human health.

The conventional solid-liquid extraction method is alternatively used to obtain phytochemicals. Extraction occurs as result of diffusion of the compound of interest to the solvent, this phenomenon is produced by the affinity and selectivity of the solvent used (Takeuchi et al., 2009). Solvents such as ethanol, methanol, and acetone are often used in the extraction of phytochemicals, these solvents are acidified with hydrochloric acid in order to improve the stability of anthocyanins (Lees \& Francis, 1972; Rodriguez-Saona \& Wrolstad, 2001). The concern about the use of toxic solvents in the extraction of phytochemicals was approached by Pedro et al., (2016), observed good results in the extraction of phytochemicals with ethanol acidified with citric acid. Some factors that significantly influenced the extraction were temperature, solvent concentration, solid-liquid ratio, and time (Li et al., 2012; Pedro et al., 2016). It was observed that in the extraction of anthocyanins other compounds are also extracted (Pedro et al., 2016).

Due to the current interest in the consumption of foods with functional properties, it is necessary to develop efficient processes, using non-toxic chemicals reagents for the safe extraction of phytochemicals. For this reason, the present research aimed to optimize the extraction of polyphenols from grape residue from

Received 27 July, 2020

Accepted 24 Sept., 2020

${ }^{1}$ Programa de Pós-graduação em Ciência e tecnologia de Alimentos, Universidade Federal Rural de Pernambuco - UFRPE, Recife, PE, Brasil

${ }^{2}$ Escuela Profesional de Ingeniería Agroindustrial, Universidad Nacional Amazónica de Madre de Dios - UNAMAD, Puerto Maldonado, Madre de Dios, Perú

${ }^{3}$ Programa de Pós-graduação em Biometria e Estatística Aplicada, Universidade Federal Rural de Pernambuco - UFRPE, Recife, PE, Brasil

*Corresponding author: m.inesdcd@gmail.com 
the juice industry, aiming their use in food processing, and to evaluate their stability during storage.

\section{Materials and methods}

\subsection{Sample}

A total of $25 \mathrm{~kg}$ of grape residue from cv. Isabel (Vitis labrusca) was supplied by a pulp processing industry in the municipality of Goiana, Pernambuco, Brazil. The residue was homogenized and divided into sample units of $800 \mathrm{~g}$ each and stored at $-18 \pm 1{ }^{\circ} \mathrm{C}$.

\subsection{Chemical reagents}

The reagents used in the extraction were: absolute ethanol 99.9\% (Merck KGaA, Emsure, Germany) and citric acid 99.5\% (Química Moderna, Brazil). The reagents used in the quantitative analyzes were: hydrochloric acid, potassium chloride, sodium acetate, chloroform and acetone (Fmaia, Brazil); Folin-Ciocalteu's reagent (Merck, Germany); Gallic acid 98\% (Vetec Química fina Ltda, Brazil); Sodium carbonate (Sigma-Aldrich, Brazil) and potassium metabisulphite $96 \%\left(\mathrm{~K}_{2} \mathrm{~S}_{2} \mathrm{O}_{5}\right)$ (Dinâmica, Química Contemporânea Ltda, Brazil).

\subsection{Preparation of the residue for extraction}

The residue was oven dried (MARCONI, MA035, Brazil) with air circulation at $40{ }^{\circ} \mathrm{C}$ for $18 \mathrm{~h}$. The dried residue was ground in a knife mill with cooling (TECNAL, TE-631/2, Brazil) for $1 \mathrm{~min}$ at 7,000 rpm. The flour was sieved sequentially with two stainless steel sieves (Bertel, Caieiras, Brazil) of 42 and 80 mesh. The residue with a particle size between 355-180 $\mu \mathrm{m}$ was selected for the experiments. This residue was vacuum packed at $98.66 \mathrm{kPa}$ in a vacuum sealer (SELOVAC, 200B, Brazil) and stored protected from light at $-18 \pm 1^{\circ} \mathrm{C}$ until the experiments were run.

\subsection{Characterization of the wet and dry residue}

\section{Moisture content}

The moisture of the residue was determined by infrared radiation before and after drying, an infrared apparatus (Marte, ID50, Brazil) was used with a constant temperature of $105^{\circ} \mathrm{C}$.

\section{Quantification of total anthocyanins, total flavonols and total phenolics}

Total anthocyanins (TA) and total flavonols (TF) were quantified following the methodology of Lees \& Francis (1972), Using $3 \mathrm{~g}$ of the wet residue and $2 \mathrm{~g}$ of the dried residue for extraction. Absorbance readings were performed on a UVVisible spectrophotometer (SHIMADZU, UV-1650PC, Japan) at 535 and $374 \mathrm{~nm}$, for TA and TF, respectively. Calculations were performed with Equations 1 and 2, TA were expressed in $\mathrm{mg}$ of cyanidin-3-glycoside per $100 \mathrm{~g}$ of sample and TF in $\mathrm{mg}$ equivalent in quercetin per $100 \mathrm{~g}$ of sample.
$T A=\frac{A b s_{535 n m} x D F}{98.2}$

$T F=\frac{A b s_{374 n m} x D F}{76.5}$

Where: $D F$ - Dilution factor; Abs - Absorbance; TA - Total anthocyanins (mg/100g); TF - Total flavonols (mg/100g)

Total phenolics (TP) were quantified from the extracts obtained to quantify TA and TF, following the methodology of Wettasinghe \& Shahidi (1999). The absorbance was read at $725 \mathrm{~nm}$ on the UV-Visible Spectrophotometer. TP was calculated with a standard curve constructed with gallic acid and the results were expressed in mg equivalent in gallic acid (EAG) per $100 \mathrm{~g}$ of sample.

\subsection{Experimental design for extractions}

The effect of temperature $\left(\mathrm{X}_{1}\right)$, solid:liquid ratio $\left(\mathrm{X}_{2}\right)$ and time $\left(\mathrm{X}_{3}\right)$ on TA, TF and TP extraction were investigated. The tests were performed according to the Box-Behnken design adjusted to the three independent variables, with total of 15 assays including three replicates at the center point (Table 1). The levels of the variables were adjusted according to the experiences of Pedro et al. (2016), as well as the extraction assays. The extractions were performed in a rotary evaporator (Heidolph, Laborota 4000), with agitation of $90 \pm 2 \mathrm{rpm}$ at atmospheric pressure according to the experimental design. $2 \mathrm{~g}$ of the dry residue was mixed with the extraction solvent (ethanol acidified with $1.5 \mathrm{~mol} / \mathrm{L}$ citric acid solution in a ratio of $80 / 20 \mathrm{vol} / \mathrm{vol}$ ). After completion of the extraction, the sample-solvent mixture was filtered and the volume of the filtrate was checked to $100 \mathrm{~mL}$ with the extraction solvent. The extracts were stored at $-18 \pm 1^{\circ} \mathrm{C}$ in amber glass vials. The TA, TF and TP were quantified by reading the absorbance of the extracts after $24 \mathrm{~h}$, as described by Lees \& Francis (1972).

\subsection{Elaboration and characterization of the optimized extract concentrate}

The optimized concentrate extract (OCE) was prepared following the flowchart as shown in Figure 1. For each extraction was used $20 \mathrm{~g}$ of the dried residue. The parameters of each operation were established in the extraction assays and after the optimization of the extraction. The concentration was added to the process for the purpose of removing the ethanol.

The OCE was analyzed to quantify the monomeric anthocyanins in $\mathrm{mg} / \mathrm{L}$ of Malvidine-3,5-diglucoside (Toaldo et al., 2013) by the $\mathrm{pH}$-differential method (Lee et al., 2005). TP and TF were quantified by reading the absorbance according to the methodology described by Lees \& Francis (1972). The $\mathrm{pH}$ was measured with the aid of a pH meter, TECNAL, Tec-3MP, Brazil (Association of Official Analytical Chemistry, 2002). Solids soluble in ${ }^{\circ}$ Brix were determined by reading on an automatic refractometer at $25^{\circ} \mathrm{C}$ (REICHERT, r2i300, USA). The water activity was determined by the direct method at $25^{\circ} \mathrm{C}$ in an Aqualab (4T analyzer, DECAGON DEVICES, Brazil). The color was characterized using the CIELAB parameters $\left(L^{*} a^{*} b^{*}\right)$ as described by McGuire (1992). 
Table 1. Box-Behnken design with experimental and fitted data for the extraction of polyphenols from grape residue cv. Isabel.

\begin{tabular}{|c|c|c|c|c|c|c|c|c|c|}
\hline \multirow{3}{*}{ Run } & \multicolumn{3}{|c|}{$\begin{array}{l}\text { Real value and coded independent } \\
\text { variables }\end{array}$} & \multicolumn{6}{|c|}{ Response variables } \\
\hline & \multirow{2}{*}{$\mathrm{X}_{1}$} & \multirow{2}{*}{$\mathbf{X}_{2}$} & \multirow{2}{*}{$\mathrm{X}_{3}$} & \multicolumn{2}{|c|}{ TA } & \multicolumn{2}{|c|}{ TF } & \multicolumn{2}{|l|}{ TP } \\
\hline & & & & Experimental $^{\star}$ & Fitted & Experimental $^{*}$ & Fitted & Experimental $^{*}$ & Fitted \\
\hline 2 & $20(-1)$ & $1 / 25(1)$ & $50(0)$ & $16.49 \pm 1.55^{\mathrm{e}}$ & 16.85 & $56.06 \pm 2.56^{\mathrm{f}}$ & 56.07 & $625.00 \pm 11.81^{\mathrm{jk}}$ & 632.07 \\
\hline 3 & $60(1)$ & $1 / 15(-1)$ & $50(0)$ & $21.19 \pm 1.71^{\mathrm{bcd}}$ & 20.83 & $68.01 \pm 3.02^{\mathrm{b}}$ & 67.99 & $785.71 \pm 5.91^{b}$ & 778.64 \\
\hline 5 & $20(-1)$ & $1 / 20(0)$ & $20(-1)$ & $18.26 \pm 1.03^{\text {cde }}$ & 18.01 & $55.32 \pm 1.67^{\mathrm{f}}$ & 56.28 & $623.51 \pm 16.75^{\mathrm{jk}}$ & 644.53 \\
\hline 6 & $20(-1)$ & $1 / 20(0)$ & $80(1)$ & $18.46 \pm 1.03^{\text {cde }}$ & 17.07 & $58.89 \pm 3.43^{\text {cdef }}$ & 57.39 & $586.31 \pm 7.84^{1}$ & 576.45 \\
\hline 7 & $60(1)$ & $1 / 20(0)$ & $20(-1)$ & $19.97 \pm 0.73^{\text {bcde }}$ & 21.36 & $65.84 \pm 1.07^{\mathrm{bd}}$ & 67.34 & $651.79 \pm 19.07^{\text {fghij }}$ & 661.64 \\
\hline 8 & $60(1)$ & $1 / 20(0)$ & $80(1)$ & $29.24 \pm 1.71^{\mathrm{a}}$ & 29.49 & $77.92 \pm 2.42^{\mathrm{a}}$ & 76.96 & $880.95 \pm 15.19^{\mathrm{a}}$ & 859.93 \\
\hline 12 & $40(0)$ & $1 / 25(1)$ & $80(1)$ & $22.72 \pm 1.93^{\mathrm{b}}$ & 23.75 & $65.35 \pm 2.76^{\mathrm{be}}$ & 66.84 & $699.40 \pm 17.34^{\mathrm{de}}$ & 702.19 \\
\hline $13(\mathrm{C})$ & $40(0)$ & $1 / 20(0)$ & $50(0)$ & $18.85 \pm 0.31^{\text {bcde }}$ & 19.60 & $60.72 \pm 0.83^{\mathrm{bf}}$ & 62.06 & $663.69 \pm 6.82^{\mathrm{ei}}$ & 681.30 \\
\hline $14(\mathrm{C})$ & $40(0)$ & $1 / 20(0)$ & $50(0)$ & $18.06 \pm 0.56^{\text {cde }}$ & 19.60 & $59.58 \pm 0.93^{\text {cdef }}$ & 62.06 & $671.88 \pm 8.05^{\mathrm{ef}}$ & 681.30 \\
\hline $15(\mathrm{C})$ & $40(0)$ & $1 / 20(0)$ & $50(0)$ & $21.89 \pm 2.16^{\mathrm{bc}}$ & 19.60 & $65.89 \pm 3.62^{\mathrm{bc}}$ & 62.06 & $708.33 \pm 7.84^{\mathrm{cd}}$ & 681.30 \\
\hline
\end{tabular}

$\mathrm{X}_{1}$ : Temperature $\left({ }^{\circ} \mathrm{C}\right) ; \mathrm{X}_{2}$ : solid/liquid rate $(\mathrm{g} / \mathrm{mL}) ; \mathrm{X}_{3}$ : Time ( $\left.\mathrm{min}\right) ;$ TA: Total anthocyanins $(\mathrm{mg} / 100 \mathrm{~g}) ; \mathrm{TF}$ : Total flavonols (mg/100 g); TP: Total phenolics (mg EAG/100 g); (C): central point; ${ }^{*}$ Mean values \pm standard deviation $(\mathrm{n}=3)$. The means in the column follow equal letters in the experimental data indicate statistically significant differences, according to Tukey test $(\mathrm{p} \leq 0.05)$.

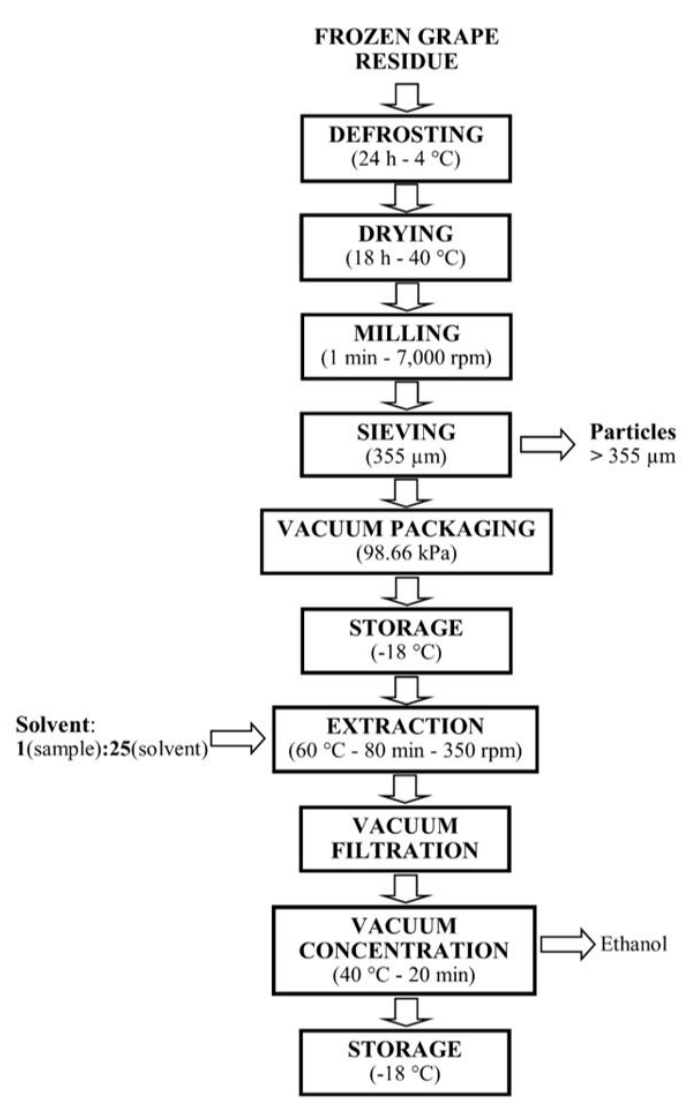

Figure 1. Flowchart of the process of elaboration of optimization extract concentrate of grape residue.

\section{Percentage of polymeric color of optimized extract concentrate}

The percentage of the polymeric color was determined according to the Giusti, \& Wrolstad (2001), with Equation 3. The diluted OCE (1 part OCE and 4 parts distilled water) was used for the determinations.

Polymeric color $(\%)=\left(\frac{\text { Polymeric color }}{\text { Color density }}\right) \times 100$

The polymeric color and color density were calculated with Equation 4, using absorbance readings of the OCE diluted with bleaching treatment and without bleaching, respectively.

$\left[\left(A_{420 \mathrm{~nm}}-A_{700 \mathrm{~nm}}\right)+\left(A_{520 \mathrm{~nm}}-A_{700 \mathrm{~nm}}\right)\right] x D F$

Where: $A$ - Absorbance; $D F$ - Dilution factor

\subsection{Stability study of anthocyanins}

The OCE was packed in $20 \mathrm{~mL}$ amber vials and stored at $4{ }^{\circ} \mathrm{C}$ in a refrigerated incubator (BOD, TECNAL, TE-371, Brazil). The degradation of the monomeric anthocyanins was monitored by the pH-differential method (Lee et al., 2005) and the polymeric color by the method described in item 2.6.1. The determinations were performed initially every 3 days and after 21 days every 5 days for a period of 83 days. The degradation kinetics of the monomeric anthocyanins and 
the increase of the polymeric color were determined using the first order reaction model as proposed by Sharma et al., (2016), using Equation 5.

$$
C=\mathrm{C}_{0} e^{ \pm \mathrm{k}^{*} t}
$$

Where: $t$ - Time; $\mathrm{k}$ - The first-order kinetic rate constant; $\mathrm{C}_{0}$ - Concentrations of monomeric anthocyanins $\left(\mathrm{mg} \cdot \mathrm{L}^{-1}\right)$ and polymeric color (\%) at time zero; $\mathrm{C}$ - Concentrations of monomeric anthocyanins (mg. $\left.\mathrm{L}^{-1}\right)$ and polymeric color (\%) at time $t$.

The half-life time of the monomeric anthocyanins was calculated with Equation 6.

$$
t_{1 / 2}=\frac{\ln (2)}{\mathrm{k}}
$$

Where: $\mathrm{k}$ - The first-order kinetic rate constant; $t_{\frac{1}{2}}$ - Half-life time

\subsection{Statistical analysis}

The data of the assays for optimization of the extraction were submitted to analysis of variances (ANOVA) and the differences among the means by Tukey test $(p<0.05)$. The normality and homoscedasticity of the ANOVA residues were obtained by the Anderson-Darling and Breush-Pagan tests, respectively. The analysis of multiple linear regression by response surface methodology (RSM) was performed using the Equation 7 model:

$$
Y_{i}=\beta_{0}+\sum_{i=1}^{k} \beta_{i} X_{i}+\sum_{i=1}^{k} \beta_{i i} X_{i}^{2}+\sum_{i>j}^{k} \beta_{i j} X_{i} X_{j}
$$

Where the response function $\left(Y_{\mathrm{i}}\right)$ is composed of linear, quadratic and interactive components. The constant $\beta_{0}$ denotes the intercept of the model; $\mathrm{B}_{\mathrm{i}}, \beta_{\mathrm{ii}}$ and $\beta_{\mathrm{ij}}$ represent the coefficients of the linear, quadratic and iterative components of the model, respectively. $X_{i}$ and $X_{j}$ are the independent variables, and $k$ represents the number of factors that were investigated. The quality of the fit of the experimental data to the model was evaluated by the test of lack of fit, coefficient of ordinary and adjusted regression. The assumption of normality of residuals was verified by Anderson-Darling test. Simultaneous optimization of TA, TF and TP extraction was performed using the desirability function (Derringer \& Suich, 1980).

The degradation kinetics of monomeric anthocyanins and the increase in polymeric color of OCE were adjusted by non-linear regression. The normality of the residues and the ordinary determination coefficient were used to evaluate the quality of the adjustment. Statistical analyzes were performed with the aid of MATLAB ${ }^{\circledR}$ R2010a 7.10.0.499 software (MathWorks, USA).

\section{Results and discussion}

\subsection{Characterization of the wet and dry residue}

The moisture content of the wet residue was $51.39 \pm 1.53 \mathrm{~g} / 100 \mathrm{~g}$ wet basis (w.b.), a near content was observed in the grape residue of vinification by Minjares-Fuentes et al. (2014). The dried residue had a moisture content of $5.33 \pm 0.44 \mathrm{~g} / 100 \mathrm{~g}$ w.b., a similar value was reported by Ribeiro et al. (2015). The TA content of the residue before and after drying was $11.51 \pm 0.95 \mathrm{mg} / 100 \mathrm{~g}$ and $28.32 \pm 0.34 \mathrm{mg} / 100 \mathrm{~g}$, respectively. The Higher value was observed by Liazid et al. (2011) in the grape skin of $\mathrm{cv}$. Tintilla Rota ( $V$. vinifera), reporting a content of $154.59 \mathrm{mg} / 100 \mathrm{~g}$. The TA content observed in this work is probably due to the low anthocyanin content of the cv. Isabel (Yamamoto et al., 2015), and/or the culture conditions (Zhou et al., 2020; Sun et al., 2019).

The TP content of the wet and dry residue was $273.20 \pm 18.27 \mathrm{mg}$ EAG/100 g and $804.26 \pm 44.53 \mathrm{mg}$ EAG/100 g, respectively. The phenolic content of the grape residue is influenced by the grape cultivar and the processing conditions (Abe et al., 2007). This fact was observed in the skin of grapes of several cultivars derived from ten different vinification processes (Harsha et al., 2013).

The TF content in the wet and dry residue was 21.65 $\pm 0.64 \mathrm{mg} / 100 \mathrm{~g}$ and $58.95 \pm 0.48 \mathrm{mg} / 100 \mathrm{~g}$, respectively. Harsha et al. (2013) reported similar contents in grape skins derived from various vinification processes. In a similar study, it was reported close levels in Cabernet Franc and Sauvignon grapes skins derived from vinification (Barcia et al., 2014).

\subsection{Surface responses}

The experimental data from the extraction assays are presented in Table 1. The normality and homoscedasticity of ANOVA residues and multiple linear regression analysis were verified by the Anderson-Darling and Breush-Pagan test ( $p>0.05$ ), respectively. Norman (2010), say that parametric statistics are robust when data are not normal. However, obtaining efficient estimates is linked to adherence to the ANOVA assumptions for the residues.

Significant statistical differences $(\mathrm{p}<0.05)$ were found between the essays and the means of the essays, by ANOVA and the Tukey test, respectively. The regression results are shown in Table 2, the quadratic model was significant $(\mathrm{p}<0.05)$ for TA, TP and TF. Likewise, there was no lack of fit significant $(\mathrm{p}>0.05)$ for the three data groups. The adjusted models for TA, TP and TF explain 93\%, 94\% and 94\%, respectively, the variation of the response variables.

\section{Response surface for extraction of total anthocyanins}

In Table 2, it is observed that the linear components of temperature $\left(\mathrm{X}_{1}\right)$, solid:liquid ratio $\left(\mathrm{X}_{2}\right)$, time $\left(\mathrm{X}_{3}\right)$, the interaction between the two $\left(\mathrm{X}_{1} \mathrm{X}_{2}\right)$ and the intercept were significant and positive. This indicates that these components increase the value of the TA content. The temperature influenced significantly the extraction of anthocyanins from residues of Tulipa gesneriana 
Table 2. Estimated regression coefficients for the model quadratic polynomial and the ANOVA of the fitted model.

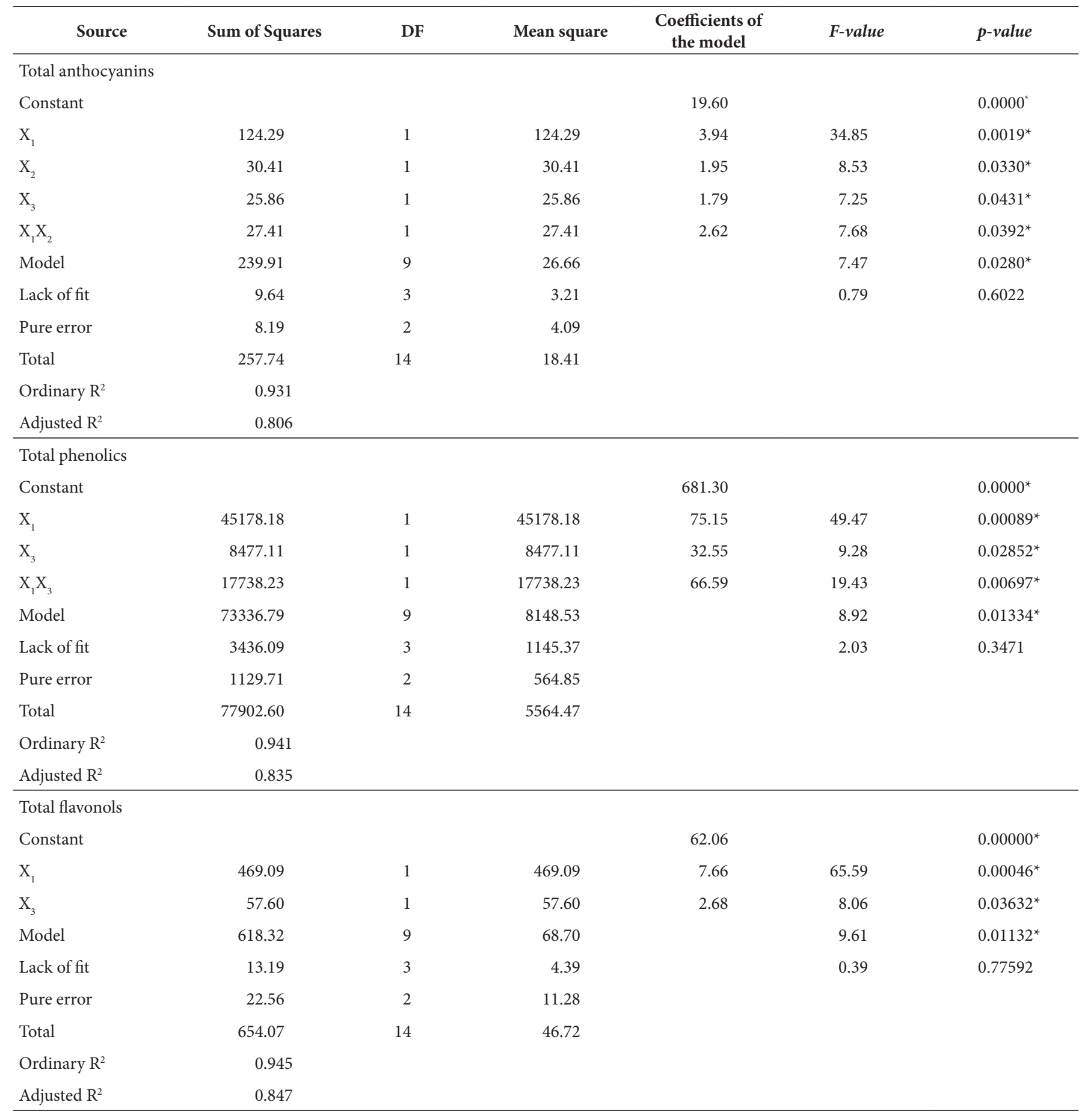

DF: Degrees of freedom; ${ }^{*}$ Means significance $(\mathrm{p}<0.05) ; \mathrm{X}_{1}$ : Temperature $\left({ }^{\circ} \mathrm{C}\right) . \mathrm{X}_{2}$ : solid/liquid rate $(\mathrm{g} / \mathrm{mL})$ and $\mathrm{X}_{3}$ : Time $(\mathrm{min})$.

L. petals (Arici et al., 2016) and in Nitraria tangutorun seeds (Sang et al., 2017).

\section{Response surface for extraction of total phenolics}

The coefficients of the linear components of the temperature $\left(X_{1}\right)$, time $\left(X_{3}\right)$, of the interaction between the temperature with time $\left(\mathrm{X}_{1} \mathrm{X}_{3}\right)$ and the intercept were significant and positive (Table 2 ). The temperature had a significant effect on the microwave-assisted extraction of phenolic compounds in grape skins (Cvjetko Bubalo et al., 2016). Extraction of phenolic compounds from grape residue was significantly influenced by temperature and solid:liquid ratio (Pinelo et al., 2005).

\section{Response surface for extraction of total flavonols}

The coefficients of the linear components of temperature $\left(\mathrm{X}_{1}\right)$, time $\left(\mathrm{X}_{3}\right)$ and intercept were significant $(\mathrm{p}<0.05)$ and 
positive indicating that these components tend to increase TF extraction. The time had a significant influence on the extraction of flavonols from citrus flowers (González-Centeno et al., 2014)

\subsection{Extraction optimization}

Equations 8, 9 and 10, with significant components determined by RSM, were used for optimization. Extractions of TA, TF and TP were optimized simultaneously by the desirability function. The individual desirability $\left(d_{1}, d_{2}\right.$ and $\left.d_{3}\right)$ was calculated for TA, TP and TF by unilateral transformation. The global desirability (D) was obtained by the geometric mean of the individual desirability's.

$$
\begin{aligned}
& T A=20.66-3.94 X_{1}-1.94 X_{2}-1.79 X_{3}+2.61 X_{1} X_{2} \\
& T F=63.00+7.65 X_{1}+2.68 X_{3} \\
& T P=682.49-75.14 X_{1}-32.55 X_{3}+66.59 X_{1} X_{3}
\end{aligned}
$$

Where: $T A$ - Total anthocyanins; $T F$ - Total flavonols; TP Total phenolics; $X_{1}$ - Temperature $\left({ }^{\circ} \mathrm{C}\right) ; X_{2}$ - Solid/liquid rate $(\mathrm{g} / \mathrm{mL}) ; X_{3}-$ Time $(\mathrm{min})$

The conditions that maximize the three response variables obtained for a $\mathrm{D}=0.77$, was the temperature of $60^{\circ} \mathrm{C}$, solid:liquid ratio of $1 / 25 \mathrm{~g} / \mathrm{mL}$ and $80 \mathrm{~min}$. Under these conditions it is possible to extract $30.96 \mathrm{mg} / 100 \mathrm{~g}$ of TA; $73.34 \mathrm{mg} / 100 \mathrm{~g}$ TF and $856.78 \mathrm{mg}$ EAG/100g TP. Similar optimized extraction temperature was observed in the extraction of anthocyanins from grape skins by Li et al. (2012). Different optimized conditions were observed in the extraction of anthocyanins from black rice (Pedro et al., 2016).

The predicted value for TP extraction was higher than that reported by González-Centeno et al. (2014), on ultrasound extraction of grape residue. In another study, higher near total phenolics content of $957 \mathrm{mg}$ EAG/100 $\mathrm{g}$ was reported in the grape residue (Goula et al., 2016). The value predicted for the extraction of total flavonols was higher than reported by GonzálezCenteno et al (2014), on ultrasonic extraction from grape residue.

\subsection{Elaboration and characterization of the optimized extract concentrate}

Approximately $200 \mathrm{~mL}$ of OCE was obtained for each liter of alcoholic extract. Table 3 shows the results of the characterization. Most soluble solids in the extract are assumed to be the citric acid used in the acidification of the extraction solvent. Water activity indicates that there is water available for chemical and enzymatic reactions, which could accelerate the degradation of phytochemicals (Schwartz et al., 2010). The $\mathrm{pH}$ of the extract was similar to that reported as convenient to maintain the stability of anthocyanins (Sui et al., 2014).

The positive and superior value of parameter $\mathrm{a}^{*}$ compared to $\mathrm{b}^{*}$ indicates that OCE has a predominantly red color, with luminosity $\left(\mathrm{L}^{*}\right)$ of 24.32 . The similar color was observed in wines without aging by Avizcuri et al. (2016). The percentage of OCE polymeric color indicates the presence of degraded and/or polymerized anthocyanins, probably generated in the grape processing in the industry (Kirca, \& Cemeroglu, 2003). Extracts with composition and similar characteristics obtained in this work are being applied in yogurts (Chouchouli et al., 2013).

\subsection{Stability of anthocyanins}

Table 4 shows the mean values of the monomeric anthocyanin content and the percentage of polymeric color determined periodically during 83 days of storage at $4{ }^{\circ} \mathrm{C}$. In Table 5 , the kinetic

Table 3. Result of the characterization of the optimized extract concentrate.

\begin{tabular}{lc}
\hline \multicolumn{1}{c}{ Analysis } & Value $^{*}$ \\
\hline Soluble solid $\left({ }^{\circ}\right.$ Brix $)$ & $34.07 \pm 2.18$ \\
Water activity & $0.94 \pm 0.01$ \\
Color: & \\
$\mathrm{L}^{*}$ & $24.32 \pm 1.88$ \\
$\mathrm{a}^{*}$ & $26.32 \pm 4.12$ \\
$\mathrm{~b}^{*}$ & $5.14 \pm 3.27$ \\
$\mathrm{pH}$ & $2.14 \pm 0.15$ \\
Monomeric anthocyanins (mg/L) & $39.95 \pm 1.39$ \\
Total flavonols (mg/L) & $118.49 \pm 1.21$ \\
Total phenolics (mg EAG/L) & $2257.44 \pm 78.14$ \\
Polymeric color $(\%)$ & $46.63 \pm 1.46$ \\
\hline
\end{tabular}

${ }^{*}$ Mean values \pm standard deviation $(\mathrm{n}=3)$.

Table 4. Variation of monomeric anthocyanins content and percentage of polymeric color in the concentrated extract stored at $4{ }^{\circ} \mathrm{C}$

\begin{tabular}{ccc}
\hline Days & $\begin{array}{c}\text { Monomeric anthocyanins } \\
\left(\mathbf{m g} . \mathrm{L}^{-1}\right)^{*}\end{array}$ & Polymeric color ${ }^{\star}(\%)$ \\
\hline 0 & $40.73 \pm 0.94^{\mathrm{a}}$ & $45.40 \pm 1.00^{1}$ \\
3 & $37.95 \pm 3.50^{\mathrm{ab}}$ & $46.17 \pm 0.17^{\mathrm{kl}}$ \\
6 & $37.27 \pm 2.08^{\mathrm{ae}}$ & $48.63 \pm 0.47^{\mathrm{ghijk}}$ \\
12 & $37.73 \pm 1.81^{\mathrm{ad}}$ & $49.76 \pm 0.49^{\text {ghij }}$ \\
15 & $37.99 \pm 1.93^{\mathrm{ac}}$ & $48.58 \pm 0.42^{\mathrm{ghijk}}$ \\
18 & $35.99 \pm 1.48^{\mathrm{bcdeg}}$ & $49.97 \pm 0.42^{\mathrm{fj}}$ \\
21 & $36.49 \pm 0.91^{\mathrm{acdf}}$ & $49.96 \pm 0.40^{\mathrm{fi}}$ \\
31 & $35.51 \pm 1.71^{\mathrm{bcdeh}}$ & $51.38 \pm 0.25^{\mathrm{defh}}$ \\
36 & $35.18 \pm 1.25^{\mathrm{bcdei}}$ & $51.40 \pm 0.51^{\mathrm{dfg}}$ \\
41 & $34.46 \pm 0.88^{\mathrm{bcdej}}$ & $52.86 \pm 0.46^{\mathrm{cf}}$ \\
46 & $32.50 \pm 0.64^{\mathrm{fghijl}}$ & $53.39 \pm 0.51^{\mathrm{cd}}$ \\
51 & $31.85 \pm 1.21^{\mathrm{fghijm}}$ & $53.35 \pm 0.59^{\mathrm{ceg}}$ \\
58 & $32.77 \pm 0.79^{\mathrm{efk}}$ & $55.83 \pm 0.52^{\mathrm{ac}}$ \\
63 & $30.51 \pm 0.63^{\mathrm{ijk}}$ & $55.36 \pm 0.42^{\mathrm{bc}}$ \\
68 & $29.54 \pm 1.24^{\mathrm{klmn}}$ & $57.03 \pm 1.06^{\mathrm{a}}$ \\
73 & $31.79 \pm 1.96^{\text {fhijn }}$ & $58.63 \pm 1.69^{\mathrm{a}}$ \\
78 & $30.22 \pm 0.59^{\mathrm{jk}}$ & $55.77 \pm 2.95^{\text {adef }}$ \\
83 & $31.56 \pm 1.17^{\text {ghijk }}$ & $57.75 \pm 0.99^{\mathrm{ab}}$ \\
\hline
\end{tabular}

${ }^{*}$ Mean $(\mathrm{n}=3) \pm$ standard deviation. Means in the columns, followed by equal letters, do not differ statistically among themselves at a $5 \%$ probability level by the Tukey Test. 
Table 5. Kinetic parameters of the degradation of monomeric anthocyanins and generation of polymeric color of the concentrated extract in storage at $4{ }^{\circ} \mathrm{C}$.

\begin{tabular}{|c|c|c|c|c|c|}
\hline Variables & $\mathrm{C}_{0}$ & $k_{1}\left(\right.$ days $\left.^{-1}\right)$ & $\begin{array}{c}t_{1 / 2} \\
\text { (days) }\end{array}$ & SE & $\mathbf{R}^{2}$ \\
\hline $\begin{array}{l}\text { Monomeric } \\
\text { anthocyanins } \\
\left(\mathrm{mg} \cdot \mathrm{L}^{-1}\right)\end{array}$ & 40.73 & $4.096 \times 10^{-3}$ & 169.22 & 0.0002192 & 0.81 \\
\hline $\begin{array}{l}\text { Polymeric color } \\
(\%)\end{array}$ & 45.39 & $3.465 \times 10^{-3}$ & - & 0.0001509 & 0.83 \\
\hline
\end{tabular}

$k_{1}$ : Constant of the reaction of the first order model; $\mathrm{C}_{0}$ : Initial concentration; $t_{1 / 2}:$ Half-life time; SE: standard error; $\mathrm{R}^{2}$ : Coefficient of ordinary determination.

parameters for the degradation of monomeric anthocyanins and the increase of the polymeric color are observed. A 50\% lower reaction rate for anthocyanin degradation was observed in extracts of Hibiscus sabdariffa, during storage at $4{ }^{\circ} \mathrm{C}$ (Sinela et al., 2017). Cissé et al. (2012) reported a degradation rate of anthocyanins in Hibiscus sabdariffa extract, similar to that found in this present study. They also reported that the increase in polymer color is directly related to the degradation of anthocyanins.

\section{Conclusions}

The optimization of the polyphenol extraction of the grape residue with ethanol acidified with citric acid showed good results. It was observed that temperature and time significantly influenced the extraction of the three phytochemicals. While the solid:liquid ratio was only significant for the extraction of anthocyanins. The quadratic model used to adjust the experimental data was significant, although only linear and interaction components were significant. The obtained extract is rich in polyphenols and from the toxicological point of view is safe, due to the use of only ethanol and citric acid in the extraction, both considered nontoxic. Therefore, the extract can be used in the preparation of food safely. The degradation of monomeric anthocyanins and the increase of polymeric color followed a first order kinetics. The degradation rate of anthocyanins was similar to that reported in other studies, therefore, it can be inferred that the ethanol acidified with the citric acid used in the extraction of polyphenols has a positive effect on the stability of anthocyanins under refrigeration.

\section{Acknowledgements}

This study was financed in part by the Coordenação de Aperfeiçoamento de Pessoal de Nível Superior - Brasil (CAPES) - Finance Code 001. Authors are also acknowledged with the National Institute of Science and Technology of Tropical Fruits and $\mathrm{CNPq}$ for the financial support; to the Organization of American States (OAS) and to the Grupo Coimbra das Universidades Brasileiras (GCUB). The authors are also grateful to the Company "Agroindustria Frutnaã" for providing the agro industrial waste of grape cv. Isabel used is this research.

\section{References}

Abe, L. T., Mota, R. V., Lajolo, F. M., \& Genovese, M. I. (2007). Compostos fenólicos e capacidade antioxidante de cultivares de uvas Vitis labrusca
L. e Vitis vinifera L. Food Science and Technology (Campinas), 27(2), 394-400. http://dx.doi.org/10.1590/S0101-20612007000200032.

Aguilera, Y., Mojica, L., Rebollo-Hernanz, M., Berhow, M., De Mejía, E. G., \& Martín-Cabrejas, M. A. (2016). Black bean coats: new source of anthocyanins stabilized by B-cyclodextrin copigmentation in a sport beverage. Food Chemistry, 212, 561-570. http://dx.doi.org/10.1016/j. foodchem.2016.06.022. PMid:27374568.

Alwazeer, D., Bulut, M., \& Tunçtürk, Y. (2020). Fortification of milk with plant extracts modifies the acidification and reducing capacities of yoghurt bacteria. International Journal of Dairy Technology, 73(1), 117-125. http://dx.doi.org/10.1111/1471-0307.12643.

Arici, M., Karasu, S., Baslar, M., Toker, O. S., Sagdic, O., \& Karaagacli, M. (2016). Tulip petal as a novel natural food colorant source: extraction optimization and stability studies. Industrial Crops and Products, 91, 215-222. http://dx.doi.org/10.1016/j.indcrop.2016.07.003.

Association of Official Analytical Chemistry - AOAC. (2002). Official methods of analysis of the Association of Official Analytical Chemists (16th ed.). Gaithersburg: AOAC.

Avizcuri, J.-M., Sáenz-Navajas, M.-P., Echávarri, J.-F., Ferreira, V., \& Fernández-Zurbano, P. (2016). Evaluation of the impact of initial red wine composition on changes in color and anthocyanin content during bottle storage. Food Chemistry, 213, 123-134. http://dx.doi. org/10.1016/j.foodchem.2016.06.050. PMid:27451163.

Barcia, M. T., Pertuzatti, P. B., Rodrigues, D., Gómez-Alonso, S., Hermosín-Gutiérrez, I., \& Godoy, H. T. (2014). Occurrence of low molecular weight phenolics in Vitis vinifera red grape cultivars and their winemaking by-products from São Paulo (Brazil). Food Research International, 62, 500-513. http://dx.doi.org/10.1016/j. foodres.2014.03.051.

Bataglion, G. A., Da Silva, F. M. A., Eberlin, M. N., \& Koolen, H. H. F. (2015). Determination of the phenolic composition from Brazilian tropical fruits by UHPLC-MS/MS. Food Chemistry, 180, 280-287. http://dx.doi.org/10.1016/j.foodchem.2015.02.059. PMid:25766829.

Chouchouli, V., Kalogeropoulos, N., Konteles, S. J., Karvela, E., Makris, D. P., \& Karathanos, V. T. (2013). Fortification of yoghurts with grape (Vitis vinifera) seed extracts. Lebensmittel-Wissenschaft + Technologie, 53(2), 522-529. http://dx.doi.org/10.1016/j.lwt.2013.03.008.

Cissé, M., Bohuon, P., Sambe, F., Kane, C., Sakho, M., \& Dornier, M. (2012). Aqueous extraction of anthocyanins from Hibiscus sabdariffa: Experimental kinetics and modeling. Journal of Food Engineering, 109(1), 16-21. http://dx.doi.org/10.1016/j.jfoodeng.2011.10.012.

Cvjetko Bubalo, M., Ćurko, N., Tomašević, M., Kovačević Ganić, K., \& Radojčić Redovniković, I. (2016). Green extraction of grape skin phenolics by using deep eutectic solvents. Food Chemistry, 200, 159-166. http://dx.doi.org/10.1016/j.foodchem.2016.01.040. PMid:26830574.

Derringer, G., \& Suich, R. (1980). Simultaneous optimisation of several response variables. Journal of Quality Technology, 12(4), 214-219. http://dx.doi.org/10.1080/00224065.1980.11980968.

Devesa-Rey, R., Vecino, X., Varela-Alende, J. L., Barral, M. T., Cruz, J. M., \& Moldes, A. B. (2011). Valorization of winery waste vs. the costs of not recycling. Waste Management (New York, N.Y.), 31(11), 2327-2335. http://dx.doi.org/10.1016/j.wasman.2011.06.001. PMid:21752623.

Dhekney, S. A. (2016). Grape. In B. Caballero, P. M. Finglas, \& F. Toldrá (Eds.), Encyclopedia of food and health (pp. 261-265). London: Elsevier. http://dx.doi.org/10.1016/B978-0-12-384947-2.00360-3.

Giusti, M. M., \& Wrolstad, R. E. (2001). Characterization and measerument of anthocyanins by UV-visible spectroscopy. 
Current Protocols in Food Analytical Chemistry, 1, F1.2.1-F1.2.13. https://doi.org/10.1002/0471142913.faf0102s00.

González-Centeno, M. R., Knoerzer, K., Sabarez, H., Simal, S., Rosselló, C., \& Femenia, A. (2014). Effect of acoustic frequency and power density on the aqueous ultrasonic-assisted extraction of grape pomace (Vitis vinifera L.) - A response surface approach. Ultrasonics Sonochemistry, 21(6), 2176-2184. http://dx.doi.org/10.1016/j. ultsonch.2014.01.021. PMid:24548543.

Goula, A. M., Thymiatis, K., \& Kaderides, K. (2016). Valorization of grape pomace: drying behavior and ultrasound extraction of phenolics. Food and Bioproducts Processing, 100, 132-144. http://dx.doi.org/10.1016/j.fbp.2016.06.016.

Harsha, P. S. C., Gardana, C., Simonetti, P., Spigno, G., \& Lavelli, V. (2013). Characterization of phenolics, in vitro reducing capacity and anti-glycation activity of red grape skins recovered from winemaking by-products. Bioresource Technology, 140, 263-268. http://dx.doi. org/10.1016/j.biortech.2013.04.092. PMid:23707914.

Kirca, A., \& Cemeroglu, B. (2003). Degradation kinetics of anthocyanins in blood orange juice and concentrate. Food Chemistry, 81(4), 583587. http://dx.doi.org/10.1016/S0308-8146(02)00500-9.

Lee, J., Durst, R. W., \& Wrolstad, R. E. (2005). Determination of total monomeric anthocyanin pigment content of fruit juices, beverages, natural colorants, and wines by the $\mathrm{pH}$ differential method: collaborative study. Journal of AOAC International, 88(5), 1269-1278. http://dx.doi.org/10.1093/jaoac/88.5.1269. PMid:16385975.

Lees, D. H., \& Francis, F. J. (1972). Standardization of Pigment Analyses in Cranberries. HortScience, 7, 83-84.

Li, Y., Han, L., Ma, R., Xu, X., Zhao, C., Wang, Z., Chen, F., \& Hu, X. (2012). Effect of energy density and citric acid concentration on anthocyanins yield and solution temperature of grape peel in microwave-Assisted extraction process. Journal of Food Engineering, 109(2), 274-280. http://dx.doi.org/10.1016/j.jfoodeng.2011.09.021.

Liazid, A., Guerrero, R. F., Cantos, E., Palma, M., \& Barroso, C. G. (2011). Microwave assisted extraction of anthocyanins from grape skins. Food Chemistry, 124(3), 1238-1243. http://dx.doi.org/10.1016/j. foodchem.2010.07.053.

Mammadova, S. M., Fataliyev, H. K., Gadimova, N. S., Aliyeva, G. R., Tagiyev, A. T., \& Baloglanova, K. V. (2020). Production of functional products using grape processing residuals. Food Science and Technology (Campinas), 2061, 1-7. http://dx.doi.org/10.1590/fst.30419.

McGuire, R. G. (1992). Reporting of objective color measurements. HortScience, 27(12), 1254-1255. http://dx.doi.org/10.21273/ HORTSCI.27.12.1254.

Minjares-Fuentes, R., Femenia, A., Garau, M. C., Meza-Velázquez, J. A., Simal, S., \& Rosselló, C. (2014). Ultrasound-assisted extraction of pectins from grape pomace using citric acid: A response surface methodology approach. Carbohydrate Polymers, 106(1), 179-189. http://dx.doi.org/10.1016/j.carbpol.2014.02.013. PMid:24721067.

Morais, D. R., Rotta, E. M., Sargi, S. C., Schmidt, E. M., Bonafe, E. G., Eberlin, M. N., Sawaya, A. C. H. F., \& Visentainer, J. V. (2015). Antioxidant activity, phenolics and UPLC-ESI(-)-MS of extracts from different tropical fruits parts and processed peels. Food Research International, 77, 392-399. http://dx.doi.org/10.1016/j. foodres.2015.08.036.

Norman, G. (2010). Likert scales, levels of measurement and the "laws" of statistics. Advances in Health Sciences Education: Theory and Practice, 15(5), 625-632. http://dx.doi.org/10.1007/s10459-0109222-y. PMid:20146096.
O'Shea, N., Arendt, E. K., \& Gallagher, E. (2012). Dietary fibre and phytochemical characteristics of fruit and vegetable by-products and their recent applications as novel ingredients in food products. Innovative Food Science \& Emerging Technologies, 16, 1-10. http:// dx.doi.org/10.1016/j.ifset.2012.06.002.

Pedro, A. C., Granato, D., \& Rosso, N. D. (2016). Extraction of anthocyanins and polyphenols from black rice (Oryza sativa L.) by modeling and assessing their reversibility and stability. Food Chemistry, 191, 12-20. http://dx.doi.org/10.1016/j.foodchem.2015.02.045. PMid:26258696.

Pinelo, M., Rubilar, M., Jerez, M., Sineiro, J., \& Núñez, M. J. (2005). Effect of solvent, temperature, and solvent-to-solid ratio on the total phenolic content and antiradical activity of extracts from different components of grape pomace. Journal of Agricultural and Food Chemistry, 53(6), 2111-2117. http://dx.doi.org/10.1021/jf0488110. PMid:15769143.

Ribeiro, L. F., Ribani, R. H., Francisco, T. M. G., Soares, A. A., Pontarolo, R., \& Haminiuk, C. W. I. (2015). Profile of bioactive compounds from grape pomace (Vitis vinifera and Vitis labrusca) by spectrophotometric, chromatographic and spectral analyses. Journal of Chromatography. $B$, Analytical Technologies in the Biomedical and Life Sciences, 1007, 7280. http://dx.doi.org/10.1016/j.jchromb.2015.11.005. PMid:26590878.

Ribeiro, T. P., Lima, M. A. C., Alves, R. E., Gonçalves, A. L. S., \& Souza, A. P. C. (2018). Chemical characterization of winemaking byproducts from grape varieties cultivated in Vale do São Francisco, Brazil. Food Science and Technology (Campinas), 38(4), 577-583. http://dx.doi. org/10.1590/fst.01116.

Rodriguez-Saona, L. E., \& Wrolstad, R. E. (2001). Extraction, isolation, and purification of anthocyanins. Current Protocols in Food Analytical Chemistry, 1, F1.1.1-F1.1.11. https://doi.org/10.1002/0471142913. faf0101s00.

Sang, J., Sang, J., Ma, Q., Hou, X., \& Li, C. Q. (2017). Extraction optimization and identification of anthocyanins from Nitraria tangutorun Bobr. seed meal and establishment of a green analytical method of anthocyanins. Food Chemistry, 218, 386-395. http://dx.doi. org/10.1016/j.foodchem.2016.09.093. PMid:27719925.

Schwartz, S. J., von Elbe, J. H., \& Giusti, M. M. (2010). Colorants. In S. Damodaran, K. L. Parkin, \& O. R. Fennema (Eds.), Food chemistry (4th ed., pp. 571-632). London: CRC Press, Taylor \& Francis Group.

Sharma, R. J., Gupta, R. C., Singh, S., Bansal, A. K., \& Singh, I. P. (2016). Stability of anthocyanins- and anthocyanidins-enriched extracts, and formulations of fruit pulp of Eugenia jambolana ('jamun'). Food Chemistry, 190, 808-817. http://dx.doi.org/10.1016/j. foodchem.2015.06.029. PMid:26213042.

Sinela, A., Rawat, N., Mertz, C., Achir, N., Fulcrand, H., \& Dornier, M. (2017). Anthocyanins degradation during storage of Hibiscus sabdariffa extract and evolution of its degradation products. Food Chemistry, 214, 234-241. http://dx.doi.org/10.1016/j.foodchem.2016.07.071. PMid:27507471.

Sui, X., Dong, X., \& Zhou, W. (2014). Combined effect of pH and high temperature on the stability and antioxidant capacity of two anthocyanins in aqueous solution. Food Chemistry, 163, 163-170. http://dx.doi.org/10.1016/j.foodchem.2014.04.075. PMid:24912712.

Sun, X., Liu, L., Ma, T., Yu, J., Huang, W., Fang, Y., \& Zhan, J. (2019). Effect of high $\mathrm{Cu}^{2+}$ stress on fermentation performance and copper biosorption of Saccharomyces cerevisiae during wine fermentation. Food Science and Technology (Campinas), 39(1), 19-26. http://dx.doi. org/10.1590/1678-457x.24217.

Takeuchi, T. M., Pereira, C. G., Braga, M. E. M., Maróstica, M. R., Leal, P. F., \& Meireles, M. A. A. (2009). Low-pressure solvent extraction (solid-liquid extraction, microwave assisted, and ultrasound assisted) from condimentary plants. In M. A. A. Meireles (Ed.), Extracting bioactive compounds for food products: theory and applications (pp. 140-142). London: CRC Press, Taylor \& Francis Group. 
Teixeira, A., Baenas, N., Dominguez-Perles, R., Barros, A., Rosa, E., Moreno, D. A., \& Garcia-Viguera, C. (2014). Natural bioactive compounds from winery by-products as health promoters: a review. International Journal of Molecular Sciences, 15(9), 15638-15678. http://dx.doi.org/10.3390/ijms150915638. PMid:25192288.

Toaldo, I. M., Fogolari, O., Pimentel, G. C., de Gois, J. S., Borges, D. L. G., Caliari, V., \& Bordignon-Luiz, M. (2013). Effect of grape seeds on the polyphenol bioactive content and elemental composition by ICP-MS of grape juices from Vitis labrusca L. LebensmittelWissenschaft + Technologie, 53(1), 1-8. http://dx.doi.org/10.1016/j. lwt.2013.02.028.

Vital, A. C. P., Santos, N. W., Matumoto-Pintro, P. T., da Silva Scapim, M. R., \& Madrona, G. S. (2018). Ice cream supplemented with grape juice residue as a source of antioxidants. International Journal of Dairy Technology, 71(1), 183-189. http://dx.doi.org/10.1111/14710307.12412.
Wettasinghe, M., \& Shahidi, F. (1999). Evening primrose meal: a source of natural antioxidants and scavenger of hydrogen peroxide and oxygenderived free radicals. Journal of Agricultural and Food Chemistry, 47(5), 1801-1812. http://dx.doi.org/10.1021/jf9810416. PMid:10552455.

Yamamoto, L. Y., de Assis, A. M., Roberto, S. R., Bovolenta, Y. R., Nixdorf, S. L., García-Romero, E., Gómez-Alonso, S., \& Hermosín-Gutiérrez, I. (2015). Application of abscisic acid (S-ABA) to cv. Isabel grapes ( $V$. vinifera $\times$ V. labrusca) for color improvement: effects on color, phenolic composition and antioxidant capacity of their grape juice. Food Research International, 77, 572-583. http://dx.doi.org/10.1016/j.foodres.2015.10.019.

Zhou, S. H., Guo, R. R., Wei, R. F., Liu, J. B., Yu, H., Shi, X. F., Zhang, Y., Xie, T. L., \& Cheng, G. (2020). Effects of bagging or the combination of umbrella and bag treatments on anthocyanin accumulation in the berry skin of 'Kyoho' (Vitis labruscana) grape. Food Science and Technology (Campinas), 40(2), 394-400. http://dx.doi.org/10.1590/fst.41218. 